\title{
Competencies Required by Technical Drawing Teachers in Technical Colleges
}

\author{
Sulaiman Abdulwahab and Akeem Usman \\ Electrical/Electronics and Building Technology Departments, Federal College of Education (Tech.) Gombe
}

\begin{abstract}
The study was motivated by a great concern about the future and continuity of Technical Drawing in all tiers of society and our education system particularly in technical colleges. The concern stemmed from poor performance, low and declining skill practice in performance and in NABTEB Examination. Pertinent questions and doubts were raised on the required competencies of Technical Drawing Teachers currently teaching Technical Drawing in technical colleges. The study is therefore on competencies required by Technical Drawing Teachers in Technical colleges using Bauchi and Gombe States of Nigeria as a frame of reference. Three objectives were stated, research questions asked, and hypotheses formulated and tested at 0.05 level of significance. A questionnaire consisting of 54 items was structured and administered to 47 Technical Drawing Teachers in Bauchi and Gombe states. Data collected were analyzed using the Mean and t-test statistics. The study has implication for retraining, in-service training for Technical Drawing teachers and therefore recommendations involving continuous training of teachers on regular basis through workshops, seminars were made towards the implementation of the finding of the study.
\end{abstract}

Keywords: Competencies, Technical Drawing, Teachers, Technical Colleges

\section{Introduction}

Technical colleges are regarded as principal vocational institution in Nigeria. They give full training intended to prepare students for entry into various occupations (Okoro, 2006). Technical college students require knowledge and skills that will enable them to be employable, self reliant or proceed to higher education, but the result of National Business and Technical Examination Board (NABTEB) certificate examination show poor performance of technical students. According to Aina (2006), the NABTEB conducted in May 2006 shows the rate of failure (F9) as follows; Engineering 55\%, Construction trade $49 \%$ and Technical drawing $65 \%$. A close examination of this result shows that technical drawing has the highest rate of failure. This implies that most students that sat for technical drawing will not gain admission into higher institutions.

Many technical college graduates especially those in technical drawing are jobless. They are jobless not because of the absence of job opportunities in industries but because they lack technical drawing competency enough to take up the available skilled jobs (Osuala, 2007). In extension this means that the graduates of technical colleges are not competent to take up available job opportunities in industries, one should not anticipate them to be self-reliant.

Technical drawing deals with graphical representations of ideas. According to Goetsh et al (2010), technical drawing is a means of clearly and concisely communicating all of the information necessary to transform an idea or concept into a reality. Therefore, a technical drawing often contains more than just a graphical representation of its subject. It also contains dimensions, notes and specifications.

Technical drawing is taught by technical drawing teachers (Okoro, 2006). Technical drawing teachers are trained in Colleges of Education (Technical), Polytechnics and Universities. Such teachers are trained in order to teach technical drawing competently among others. Products of Colleges of Education (Technical) and Polytechnics are referred to as non-graduate teachers while products of University are regarded as graduate teachers. Technical teachers from Universities and other institutions that have undergone educational training are termed as qualified teachers. Teachers who are graduates of Universities without education background are regarded as unqualified teachers. The function of training, therefore, proceeds from the assumption that the gap between the required and actual performance, which calls for a bridge via training, is the result of inadequacies in knowledge, skills and attitudes (Okoro, 2000).

The Federal Government of Nigeria (FGN) in National Policy on Education (2004), made technical drawing as an elective subject offered at secondary school level but National Board for Technical Education (NBTE) stipulated that in technical colleges, technical drawing should be taught as a trade related course and should be taken by all students in engineering trade and construction trades except craft practice, this is due to the basic knowledge and skills it provides in engineering and construction courses.

Therefore, technical drawing as a trade related course in technical college must be studied by all students in the technical related areas for an improved academic achievement. One of the objectives of technical drawing as 
contained in the handbook published by National Institute for Educational Development (NIED), (1997) is to solve practical and technological problems through the process of communication skills which are central to design and planning. It therefore becomes imperative that only competent teacher can teach technical drawing effectively.

Competence is the ability to do something well. In the view of Hornby (2010), to be competent means that a person has the ability or power, to demonstrate knowledge, skills and attitudes that are sufficiently required to perform a given job or task. Nussel, Inglis and Wiersma (1976), explained that competency is a functional ability to apply to practical situation the essential principles and techniques of a particular subject matter or field. In this study, functional ability of teachers of technical drawing to demonstrate knowledge, skills and attitudes required in teaching technical drawing indicates competence. If on the other hand, one could not satisfactorily demonstrate knowledge, skills and attitudes required in the teaching, then the individual has a gap which shows lack of competence

\section{Statement of the Problem}

Oranu (2001) stated that technical colleges product are weak in practice of their trades. Furthermore, the standard of performance of Nigeria technicians in general is at the moment very low thereby retarding the overall productivity of the Nigeria economy (Okoro, 2001).

Unfortunately, despite all efforts by the government to ensure qualitative education at the technical colleges and bring about high competent products both in academics and employability, there have been persistent reports of high failure rate among graduates of the colleges (FGN,2001\& NABTEB, 2006). One probable cause of the high failure of students in recent years according to NABTEB (2002) chief examiners` report is partly due lack of required competencies in teaching methods by instructors employed to teach the students.

The problem of this study therefore is that technical drawing teachers are not competent to train skilled and productive technicians and craftsmen in technical colleges.

\section{Significance of the Study}

The findings of this study will be beneficial to the Ministries of Education and Researchers; they can use the result of the study to organize training workshop and seminar for technical drawing teachers in order to update their skills and knowledge in technical drawing. The Ministries will also use the findings of the study to employ teachers i.e. using the findings as an interview schedule to select qualified technical drawing teachers for technical colleges.

\section{Purpose of the Study}

To determine the Competencies required by technical drawing teachers in Bauchi and Gombe States technical colleges. Specifically the study sought to determine the competencies required by technical drawing teachers to teach:-

1. Basic and construction drawings.

2. Assembly drawing.

3. Presentation drawings.

\section{Design of the Study}

\section{Methodology}

A survey research design was adopted for the study. According to Gall., Gall and Borg (2007) a survey is a method of data collection using questionnaire or interviews to collect data from a sample that has been selected to represent a population to which the findings of the data analysis can be generalized.

\section{Area of the Study}

The area of study consists of Bauchi and Gombe States. There are nine Government Technical Colleges in two States namely; - Government Technical College Kumo, Government Day Technical College Gombe, Government Technical College Tula, Government Technical College Amada, Government Day Technical College Kwami, Government Day Technical College Deba, Government Technical College Itas/Gadau, Government Technical College Gumau and Government Day Technical College Bauchi. These colleges are chosen because they are offering technical drawing.

\section{Population of the Study}

The population for this study consists of 47 Technical Drawing Teachers of technical colleges in the two states. The data sources are from Bauchi and Gombe States Ministries of Education, Department of Science and Technical Education 2010 Staff posting. The absence of sampling is due to relative size of the population. 


\section{Instrument for data collection}

The instrument was a structured questionnaire which consists of 54 items developed by the researchers based on literature review. A four point response modes was used to determine the competencies required by Technical Drawing Teachers. Values assigned to the options are; Highly Required (HR) 4, Required (R) 3, Moderately Required (MR) 2, and Not Required (NR) 1.

\section{Validation of Instrument}

The instrument was validated by experts in technical drawing from University of Nigeria, Nsukka and Colleges of Education (Technical) Gombe. They were required to indicate any irrelevant statement(s) or wrongly worded items. The suggestions and recommendations of validators were integrated into the modified copy of the questionnaire that was used for data collection.

\section{Method for data Collection}

Fourty seven copies of the Questionnaire were administered through personal contact with the respondents.

\section{Reliability of the Instrument}

The reliability of the instrument was established using Cronbach Alpha $(\dot{\alpha})$. The validated instrument was administered to 6 teachers at Government Day Science Technical College Kafin Madaki in Bauchi State. The data obtained from the respondents were computed based on Cronbach Alpha, a the reliability coefficient of 0.80 was realized. it is regarded as reliable for the study.

\section{Method for data Analysis}

Data collected from the respondents was analyzed using mean and standard deviation obtained from responses on the four-point response categories. For decision, item with Mean of 2.50 and above was considered as having high Means, which indicates that teachers required competencies in the areas and needed to be retrained. Any item with Mean rating less than 2.50 was considered as low and that the teachers do not require competencies in that area. Hypotheses stated were tested at 0.05 level of significance using t-test of independent samples.

\section{Results}

Research Question 1. What are the competencies required by technical drawing teachers to teach basic and construction drawing?

The data for answering research question one were presented in Table one.

Table 1. Responses of respondents on the area of competencies required for basic and construction drawing.

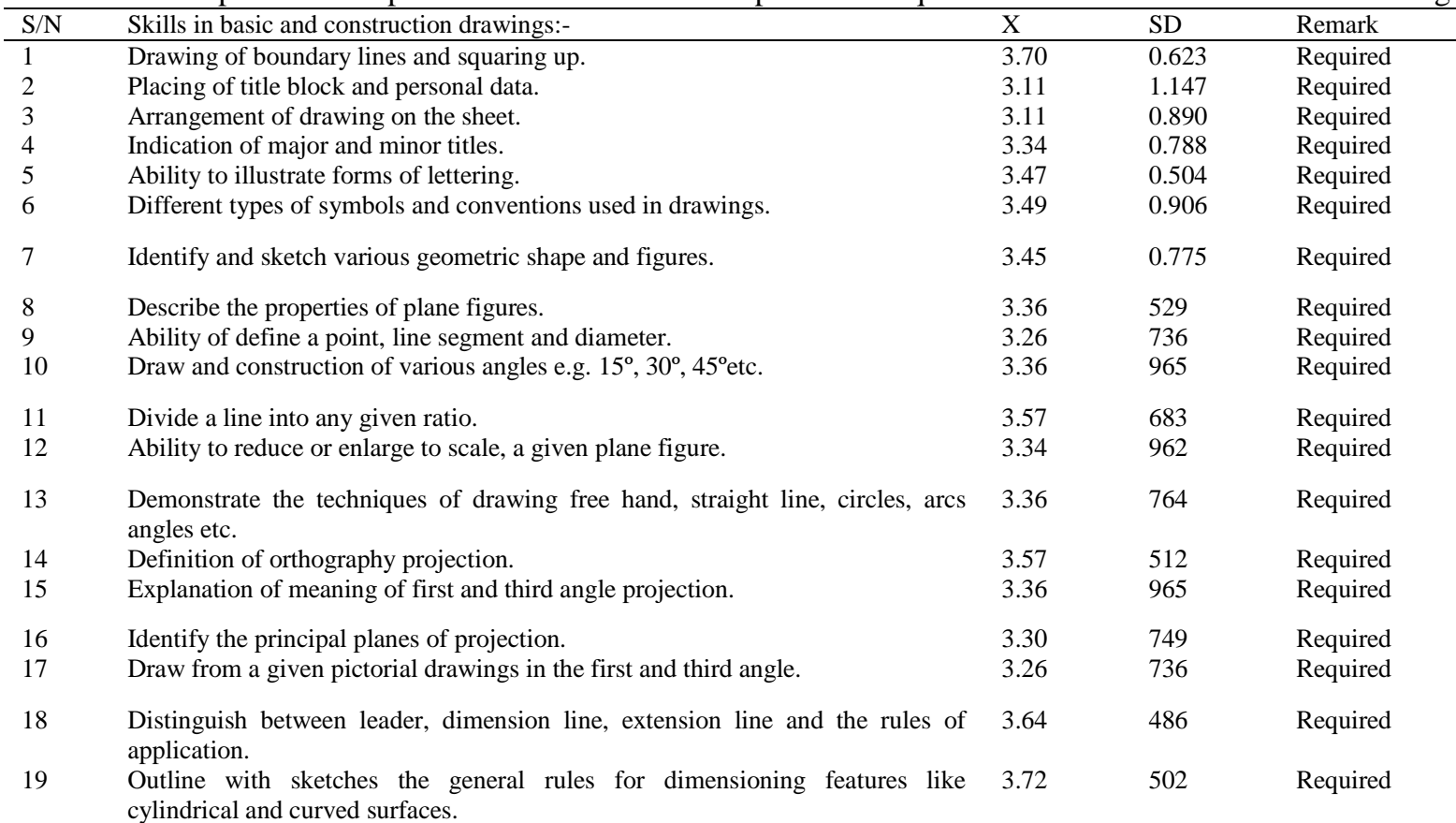




$\begin{array}{lllll}23 & \text { State the main purpose of sectioning. } & 3.64 & 640 & \text { Required } \\ 24 & \text { Illustrate and state the application of the following methods of sectioning: full } & 3.45 & 653 & \text { Required } \\ & \text { section, half section, off-set section etc. }\end{array}$

Data in Table 1 on competency required by teachers in technical drawing indicates that all the 24 are required. Item have Mean value of 2.50 and above for teachers in Government Technical Colleges.

Research Question 2. What are the competencies required by technical drawing teachesr in assembly drawings?

The data for answering research question two were presented in table two.

Table 2. Responses of respondents on the area of competencies required for assembly drawings.

\begin{tabular}{|c|c|c|c|c|}
\hline $\mathrm{S} / \mathrm{N}$ & Skills in Assembly drawings:- & $\mathrm{X}$ & SD & Remark \\
\hline 1 & $\begin{array}{l}\text { How to dismantle, prepare parts list and make pictorial/orthographic sketching } \\
\text { of the parts of a simple mechanical device. }\end{array}$ & 3.30 & .954 & Required \\
\hline 2 & $\begin{array}{l}\text { Draw orthographic views (full and sectional) of simple assemblies, Problems in } \\
\text { link Mechanism, True lengths, Angles and Surfaces. }\end{array}$ & 3.11 & .784 & Required \\
\hline 3 & Understand the principles and application of loci. & 3.17 & 1.10 & Required \\
\hline 4 & Draw and give examples of ellipse, parabola and hyperbola. & 3.09 & 905 & Required \\
\hline 5 & Use wood or paper to construct a simple link mechanism. & 3.02 & 1.327 & Required \\
\hline 7 & Determine the true angles of an inclined line to the principal planes. & 3.38 & 491 & Required \\
\hline 8 & Demonstrate and sketch the concept of auxiliary plane. & 3.40 & 771 & Required \\
\hline 9 & $\begin{array}{l}\text { Use of auxiliary and cutting plane methods to determine the line of intersection } \\
\text { of two meeting surface e.g. intersection ducts, prisms and cones etc. }\end{array}$ & 3.17 & 816 & Required \\
\hline 10 & $\begin{array}{l}\text { Use wood and paper to model different objects from the understanding of } \\
\text { development. }\end{array}$ & 3.21 & 832 & Required \\
\hline 14 & Ability to draw meshing gear profiles from given data. & 2.91 & 974 & Required \\
\hline 15 & Draw and interpret simple electrical and electronic circuits. & 3.21 & 1.020 & Required \\
\hline
\end{tabular}

Data in Table 2 on competency required by teachers in technical drawing indicates that all the 15 competency items are required. Item have Mean value of 2.50 and above for teachers in Government Technical Colleges.

Research Question 3. What are the competencies required by technical drawing teacher to teach presentation of drawings?

The data for answering research question three were presented in Table three.

Table 3. Responses of respondents on the area of competencies required for presentation of drawings.

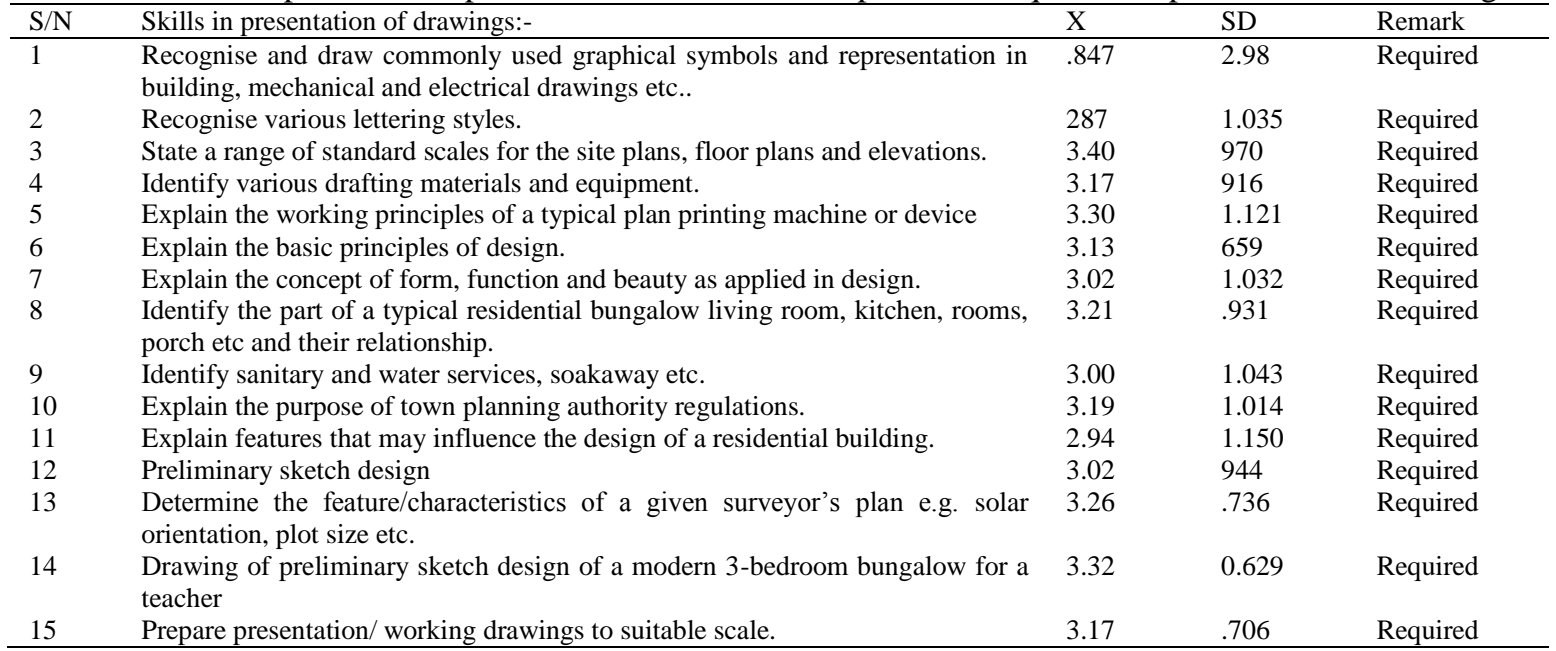

Data in Table 3 on competency required by teachers in technical drawing indicates that all the 15 are required. Item have Mean value of 2.50 and above for teachers in Government Technical Colleges. 


\section{Table 4}

Hypothesis one

H02 There is no significant difference in the mean responses of qualified and less-qualified technical drawing teachers in the competencies they require to teach basic and construction drawing.

T-test analysis of the mean rating of qualified teachers and less qualified teachers on the competency required in teaching Basic and construction drawing.

\begin{tabular}{|c|c|c|c|c|c|}
\hline $\mathrm{S} / \mathrm{N}$ & Skills in basic and construction drawings:- & $\mathrm{X}$ & $\mathrm{X}$ & t-cal & Remark \\
\hline 1 & Drawing of boundary lines and squaring up. & -998 & -992 & -0.188 & NS \\
\hline 2 & Placing of title block and personal data. & -1.587 & -1.446 & -0.532 & NS \\
\hline 3 & Arrangement of drawing on the sheet. & .230 & .230 & .0 .046 & NS \\
\hline 4 & Indication of major and minor titles. & -2.888 & 2.748 & -0.709 & NS \\
\hline 5 & Ability to illustrate forms of lettering. & -2.587 & -2.430 & -0.571 & NS \\
\hline 6 & Different types of symbols and conventions used in drawings. & -1.856 & -1.801 & 0.519 & NS \\
\hline 7 & Identify and sketch various geometric shape and figures. & -1.743 & -1.776 & -0.256 & NS \\
\hline 8 & Describe the properties of plane figures. & -2.940 & -2.574 & -0.733 & NS \\
\hline 9 & Ability of define a point, line segment and diameter. & -1.761 & -1.795 & -0.397 & NS \\
\hline 10 & Draw and construction of various angles e.g. $15^{\circ}, 30^{\circ}, 45^{\circ}$ etc. & -686 & -678 & -1.000 & NS \\
\hline 11 & Divide a line into any given ratio. & -2.152 & -1.876 & -0.383 & NS \\
\hline 12 & Ability to reduce or enlarge to scale, a given plane figure. & -2.750 & -2.430 & -0.523 & NS \\
\hline 13 & $\begin{array}{l}\text { Demonstrate the techniques of drawing free hand, straight line, } \\
\text { circles, arcs angles etc. }\end{array}$ & -956 & -902 & -0186 & NS \\
\hline 14 & Definition of orthography projection. & -3.640 & -3.195 & -0.925 & NS \\
\hline 15 & Explanation of meaning of first and third angle projection. & -1.628 & -1.653 & -0.258 & NS \\
\hline 16 & Identify the principal planes of projection. & -3.395 & -3.142 & -0.695 & NS \\
\hline 17 & Draw from a given pictorial drawings in the first and third angle. & -3.546 & -3.359 & -0.694 & NS \\
\hline 18 & $\begin{array}{l}\text { Distinguish between leader, dimension line, extension line and the } \\
\text { rules of application. }\end{array}$ & -4.832 & -4.416 & -1.137 & NS \\
\hline 19 & $\begin{array}{l}\text { Outline with sketches the general rules for dimensioning features like } \\
\text { cylindrical and curved surfaces. }\end{array}$ & -1.797 & -1.768 & -0.266 & NS \\
\hline 23 & State the main purpose of sectioning. & .166 & .167 & 0.405 & NS \\
\hline 24 & $\begin{array}{l}\text { Illustrate and state the application of the following methods of } \\
\text { sectioning: full section, half section, off-set section etc. }\end{array}$ & -891 & -886 & -0.133 & NS \\
\hline
\end{tabular}

\section{X1 - Qualified Teachers X2 - Less Qualified Teachers}

Data in Table 4 indicates that the t-test analysis of the Mean responses of qualified and less qualified teaches on required competencies in basic and construction drawing. The analysis shows that all the items have calculated $\mathrm{t}$-values of less than the table $\mathrm{t}$-value of 2.01 at 45 degrees of freedom at 0.05 levels significant, on basic and construction drawing. The null hypothesis of no significant difference between the mean rating of qualified teachers and less qualified teachers of technical drawing were therefore accepted from the analysis, it can be inferred that qualified teachers and less qualified teachers share identical opinions.

\section{Discussion of Result}

The technical competency needs of technical drawing teachers in Government Technical Colleges were analyzed and ascertained to be relevant. This finding is an indication that those competencies are complementary for effective job motivation performance and satisfaction of any worker. This is in line with Oranu (1991) who stated that personality development can be described as a combination of a press and a need. Hence, the desire to satisfy or gratify these needs directs or indicates human behaviour. The above concepts of needs have implication, among other things, to teachers in general and technical drawing teachers in particular.

According to research question one as analyzed in table 1, the finding shows that there are some competencies that are needed in basic and construction drawing teachers which could be acquired through theoretical programme. Though all respondents required that acquisition of desired competencies will be more through practical training programme. According to Hoefert (1978), a comprehensive knowledge of the competencies for basic and construction drawing is essential for teachers of technical drawing in higher education level. Hoefert explained that a competent basic and construction teacher must be skilled in the selection of appropriate materials in guiding the students to carry out successful projects using the selected materials through a planned practical activity.

In the analysis of research question two, presented in table 2, findings revealed that the competencies needed by technical drawing teachers in Assembly Drawing should be organized through practical training programme as indicated by the mean rating of the respondents' responses. This supports Akpan (1983) proposal that teaching effectiveness is a function of what to teach, how to teach, to whom it will be taught and the condition under which it will be taught. In line with this, Contrell (1973) also focused on the personal and 
professional qualities of the teacher for effective teaching and learning. Respondents agreed that the acquisition of the desired competencies will be more through practical training programme.

The research question three as analyzed in table 3 , the finding shows that there are some competencies that are needed in presentation drawing teachers which could be acquired through skillful training programme as supported by Apagu (1997), saying that quality education presupposes quality teaching which can only be achieved through mastery of the various skills in the teaching components.

\section{Conclusion}

It is through effective technical teacher education programme that the nation's technological development objective can best be achieved, since training is one of the conditions which can influence teachers' effectiveness. The following conclusion were made base on the result of the study. The findings of this study has shown some salient points that needs to be revisited by the National Board for Technical Education (NBTE) in assessing actually the competency improvement requirements of teachers of technical drawing in Government Technical Colleges. From the findings, there is the conclusion that there were shortages in the desired competencies of technical drawing teachers. As a result of this, the performance of teachers on technical drawing was limited to few competencies available.

\section{Recommendation}

The following recommendations are made from this study, since there were inadequate competent teachers of technical drawing in Government Technical Colleges. Federal government should make effort to provide enough in-service training programme for technical drawing teachers. Such in-service technical training programme should be in form of workshops, post-graduate programmes, seminars, conferences and any other forms of training that will assist the teachers of technical drawing in improving their competencies. Curriculum planners can also use the identified competencies improvement needs in planning and developing the curriculum content of the in-service training programme. The above recommendations if considered and implemented will go a long way in improving the competencies of technical drawing teachers of Government Technical Colleges.

\section{References}

[1]. Aina , O. (2006). Relevavce of secondary education business and technical qualifications as admission requirements into tertiary institution. NABTEB Newsletter, July, 2, (f), (2). 4-6 and 8, h a, 8,(X)(1). Federal government to accord priority 10 technical Vocational education. Punch Newspaper, August, 25.

[2]. Apagu, V.V. (1997). In-service needs of building technology teachers of secondary schools in Adamawa State. Unpublished Ph. D Thesis, University of Nigeria, Nsukka.

[3]. Federal Republic of Nigeria (FRN) (2004). National Policy on Education (Revised Edition) Lagos. National Education Research and Development Council (NERDC) press.

[4]. Gall, M.D., Gall, J.P., \& Borg, W.R. (2007). Educational research: An introduction. (8 ${ }^{\text {th }}$ Edition). New York: Person Education, inc.

[5]. Goetsch, D. L., Chalk, W. S., Nelson, J. A. and Rickman, R. L. (2010). Technical drawing and engineering communication (six edition). New York: Delmar Cengage Learning Publishers.

[6]. Hornby, A.S. (2010). Oxford Advance Learner's Dictionary of Current Engilish. London:Oxford University Press.

[7]. Nussel, E., Inglis, D. and Wiersma, W. (1976). The Teachers and individually guided education. London: Addison-Wesley Publishing Company.

[8]. National Business and Technical Examination Board (2006). Chief Examiners` Report of National Technical Certificate (NTC) and National Business Certificate (NBC). NABTEB Newsletter, Nov, 4 (6): 21 NRDC Press

[9]. National Institute for Educational Development (1997). Handbook on technical drawing. Okahandji NIED Press.

[10]. Okoro, O. M. (2001). Vocational industrail education. Bauchi: League of Reseacrchs in Nigeria (L.R.N.).

[11]. Okoro, O. M. (2006). Principles and methods in vocation technical education. Nsukka: University Trust Publishers.

[12]. Oranu, R. N. (1991). Vocational education and manpower development. A paper presented at the $6^{\text {th }}$ Annual Conference of Nigerian Vocational Association, held at Federal College o Education (technical), Umunze, Anambra State.

[13]. Oranu, R.N. (2001). Vocational and Technical education in Nigeria. A paper presented at the International Bureau of Education (IBE). Sub regionanal Seminar and workshop on Strategies for Teachers Coping with the New curriculum on NQV.1 1-17 A scan, Badagry.

[14]. Osuala, E. C. (2007). Introduction to research methodology, (5th edition). Onitsha: Africana Fep Publishers Limited. 